education, and perhaps the best of it, takes place outside the classroom. The candidate for the doctorate in education can no longer expect to be trained to be a polished performer behind the desk; he must learn to be something of the street-corner social worker.

This change of direction emerged from a project called the Center for Research and Development on Educational Differences. Sustained by federal research money, various inquiries "of a scientific nature" were made into what influences determine a child's capacity to learn from formal education. One study looked into the mental abilities of six-year-olds and into the contrasting patterns possessed by children from different social classes and ethnic groups around Boston. In another project, researchers worked with Negro boys from ten to fourteen years old in one of Boston's most solidly black slums. For slightly older students, courses were offered in a variety of settings for real or potential school drop-outs, and were successful in making the boys more interested in academic achievement. The result of these and a number of other experiments was the abandonment by Harvard's Graduate School of Education of the traditional idea of its purpose--the study and improvement of instruction in the classroom-for the radical belief that education's educators must be expressly concerned with what children do and can learn outside school.

Although the interests of the school range widelyfrom improving the design of Boston's school buildings to improving the teaching of physics, from Boston to Minnesota and Nigeria-its primary concern has been what it offers to the postgraduate students who come to Cambridge, Massachusetts, to take higher degrees in education. The new philosophy affects them directly. One of their programmes, instead of concentrating on teaching academic subjects in classrooms, has turned training teachers into tutors, asking them to spend time with children as individuals and to follow no set curriculum. Another, the training of primary school teachers, has asked them to study a few subjects well, rather than the usual small helping of everything; this, it is hoped, will encourage more men to become teachers of the younger age group.

These steps toward revolution will be intensified in the present academic year (although the Educational Differences Center has had to be reorganized because of educational differences with the Federal Office of Education). But the aim in the future will be the same as Dean Sizer described it for the year just concluded: "to prevent the national spirit of malaise from turning in our particular community to one of negative cynicism. Schools are failing, yes; but this does not mean that they will or should always fail".

\section{Student Participation}

THE bold recommendations that students at the Lcndon School of Economics should be granted membership of its three main governing bodies create a situation unparalleled in any university or institution in Britain or, indeed, in the world. These recommendations appear in the first report on the machinery of government of the school, signed by eighteen members of a committee chaired by Lord Bridges.

The need for changes in the way in which LSE is governed has become increasingly obvious over the past few years, as a result of the growth of the school and the complexity of its activities. This need was first seen in August 1966 when Sir Sydney Caine presented specific proposals in a paper circulated to the Court of Governors and to the academic bodies in the school. On February 2, 1967, the Court of Governors agreed to establish a joint committee consisting of members of court and the academic body, and five student members were added to this committee.

The main object of student participation, the report says, is to secure student co-operation, thereby strengthening the unity of the school. It may also help to make accurate information on the school's activities available to all students. There are two ways in which students' participation could be achieved: by "consultation" which would need to be official, involving the establishment of joint student-staff consultative committees which would meet regularly to consider in advance matters on the agenda; the alternative scheme would involve the election or nomination of appropriately qualified students to serve as members of committees or other bodies. Of these two, the committee decided that "membership" would be most advantageous.

Many of the recommendations follow the general proposals of Sir Sydney Caine's memorandum. The report recommends that there should be about sixty members of court, including twelve members of academic staff and four to eight student members. A council should be established to replace the existing Standing Committee as the central budgetary authority of the school, and it is proposed that three members of the council should be students. The committee recommends that a senate be established to have executive powers in academic matters, and that it should include five student members. Students will not be allowed, however, to become members of the Academic Boardthe forum through which all teachers would discuss and be asked to endorse important issues of policy. In addition, students would be members of some fourteen sub-committees of the senate and council, but staff appointments and promotions would be made by committees other than those on which students are members.

A minority report presented by two student members, Mr Dick Atkinson and Mr David Adelstein, lists a number of criticisms of the majority report. In the introductory comment, it is suggested that this report has limited itself to "managerially specified problems" and ignored "contemporary educational matters". In addition to challenging the assumptions and limitations of the report, $\mathrm{Mr}$ Atkinson and $\mathrm{Mr}$ Adelstein suggest a number of alternative proposals. For example, they consider that the court should comprise forty representatives of "society", including persons in trade unions, the theatre, the professions, peers of the realm and others. Furthermore, they suggest that the court should be assisted in its functions by electing a committee consisting of three governors, three staff and three students, all of whom should be members of court.

\section{Academic Awards}

Contrinuing success is reported by the Council for National Academic Awards (CNAA) in its third annual report covering the period up to September 1967. Initial misgivings about the success of the council are 